\title{
/REVIEW
}

\section{Is a Positive Western Blot Proof of HIV Infection?}

\author{
Eleni Papadopulos-Eleopulos', , Valendar F. Turner ${ }^{2}$ and John M. Papadimitriou ${ }^{3}$ \\ 'Department of Medical Physics, 2Department of Emergency Medicine. Royal Perth Hospital, Perth, Western Australia: 'Department of Pathology, \\ University of Western Australia. *Corresponding author.
}

It is currently accepted that a positive Western blot (WB) HIV antibody test is synonymous with HIV infection and the attendant risk of developing AIDS. In this communication we present a critical evaluation of the presently available data on HIV isolation and antibody testing. This evidence indicates that: (1) the antibody tests are not standardized; (2) the antibody tests are not reproducible; (3) the WB proteins (bands) which are considered to be encoded by the HIV genome and to be specific to HIV may not be encoded by the HIV genome and may in fact represent normal cellular proteins; (4) even if the proteins are specific to HIV, because no gold standard has been used to determine specificity, a positive WB may represent nothing more than cross-reactivity with non-HIV antibodies present in AIDS patients and those at risk. We conclude that the use of antibody tests as a diagnostic and epidemiological tool for HIV infection needs to be reappraised.

\footnotetext{
"... we are not simply contending in order that my" view or that of yours may prevail.

but I presume ne ought both of us to be fighting for the truth.
}

From Philebus, the Dialogues of Plato

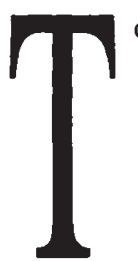
o date, the only routinely used methods for demonstrating the presence of HIV in vivo are enzymelinked immunosorbent assay (ELISA) and Western blot (WB) antibody tests. In the ELISA, the proteins are present as a mixture, and for the WB, the HIV proteins are dissociated and placed on a polyacrylamide gel slab. After electrophoresis they are transferred to a nitrocellulose membrane by electroblotting. In both ELISA and WB, the patient's serum is added to the antigen preparation. It is assumed that if HIV antibodies are present, they will react with the HIV proteins which, after washing, are visualized by an enzyme anti-human-immunoglobulin chromogen reaction. In the ELISA the reaction is read optically. For the WB, individual proteins are recognized and interpreted visually as colored bands, each of which is designated with a small " $p$ " (for protein), followed by a number, (which is the molecular mass in kilodaltons), for example p41. The WB is believed to be highly sensitive and specific, and a positive result is regarded as synonymous with HIV infection. A positive HIV status has such profound implications that no one should be required to bear this burden without solid guarantees of the verity of the test and its interpretation. In this paper, the evolution of the antibody tests, the basis of their specificity, and the validity of their interpretation are evaluated.

Acceptance of an antibody test for HIV as being scientifically valid and reliable requires the following: (1) A source of HIV specific antigens; (2) standardization; (3) determination of the test's reproducibility. Once these criteria have been met, and before the introduction of the antibody tests into clinical medicine, the test's sensitivity, specificity and predictive values must be determined by the use of a gold standard, HIV itself.

\section{Proteins Considered to be HIV Antigens}

The proteins considered to represent HIV antigens are obtained from mitogenically stimulated cultures in which tissues from AIDS patients are co-cultured with cells derived from nonAIDS patients-usually established leukaemic cell lines. Following the detection of the enzyme reverse transcriptase (RT) in the cultures, the supernatant, and more often the cell lysates, are spun in density gradients. Material which bands at $1.16 \mathrm{gm} / \mathrm{ml}$ is considered to represent "pure HIV" and consequently the proteins found at that density are considered to be HIV antigens.
The immunogenic HIV proteins are thought to be encoded by three genes, namely gag, pol and env. The gag gene encodes a precursor $\mathrm{p} 53 / 55$, which is then cleaved to $\mathrm{p} 24 / 25$ and $\mathrm{p} 17 / 18$. The pol gene encodes $\mathrm{p} 31 / 32$, and the env gene encodes the precursor protein pl60, which is cleaved to p120 and p4l/p45 (ref. 1).

The p120 protein. The generally accepted view is that p120 and $p 41$ are cleavage products of p160, which is found only in infected cells and not in the virus. However, p120 is a component only of the knobs (spikes) on the surface of HIV particles; the knobs are found only in the budding (immature) particles; and not in cell free (mature) particles; and immature particles are "very rarely observed"? Despite these findings, when "purified HIV" is tested against AIDS sera, strong bands corresponding to pl20 and p160 develop. The solution to these contradictions was found when it was shown that $\mathrm{p} 80$ (vide infra) and "the components visualized in the $120-160-\mathrm{kDa}$ region do not correspond to gp 120 or its precursor but rather represent oligomers of gp4l"

The $\mathrm{p} 41$ protein. $\mathrm{p} 41$ is one of the proteins detected by both Gallo's and Montagnier's groups in the first HIV isolates. However, Montagnier and his colleagues observed that AIDS sera reacted with a p4l protein both in HIV and HTLV-I infected as well as non-infected cells, and concluded that the p41 band "may be due to contamination of the virus by cellular actin which was present in immunoprecipitates of all the cell extracts"4. Although Gallo's group did not find such reaction with p41 in non-infected cells, they did find a p 80 protein and concluded that the reaction was "non-specific"s.

Actin is a ubiquitous protein which is found in all cells as well as bacteria and several viruses. Well-studied retroviruses, such as the mouse mammary tumour virus and Rous sarcoma virus, have also been shown to contain actin of cellular origin and it has been postulated that this protein plays a key role in both retroviral assembly and budding ${ }^{6.7}$. It is also known that oxidation of cellular sulphydryl groups, as is the case in AIDS patients ${ }^{8}$, is correlated with assembly of polymerized actin ${ }^{9}$, and that the level of actin antibody binding to cells is determined by the physiological state of the cells. For this reason actin antibody binding to cells has been proposed "as a sensitive marker for activated lymphocytes" 10

Platelets from healthy individuals also contain a $p 41 / 45$ pro- 


\section{IMAGE \\ UNAVAILABLE FOR COPYRIGHT REASONS}

FIGURE 1. (A) "Cord blood T-lymphocytes infected with virus" (HIV-1) were lyeed and the supernatant of a $10,000 \mathrm{~g}$ centrifugation of the cell lyeate was immunoprecipitated with sera from patients with lymphadenopathy (P); a healthy donor (h); goat antiserum to HTLVI p24 (G); normal goat serum (g). (B) As (A) but cells infected whth HTLKI Insteed of HIV-1. (C) The cell free supernatent from the cultures of "cord blood T-lymphocytes infected with virus" (HIK1) was ultracentrifuged for one hour at $50,000 \mathrm{rev} / \mathrm{m} / \mathrm{n}$. The pellett wes banded in sucrose density gradiente. Material which banded at $1.16 \mathrm{gm} / \mathrm{ml}$ (the complete virus) was immunoprecipitated with the above sera but instead of normal goat serum, serum from another healthy donor (h) was used. Although in the published stripe it is hard If not Impossible to distingulsh amy bands, in the text', it is stated that "three major protelns could be seen: the p25 protein and proteins with molecular weights of 80,000 and 45,000" (From reference 4, with permission).

tein which reacts with sera from homosexual men with AIDS and immune thrombocytopenic purpura (ITP) and which "represents non-specific binding of IgG to actin in the platelet preparation""ll.

The $\mathbf{p 2}$ protein. In 1987 Henderson isolated the $\mathrm{p} 30-32$ and p34-36 of "HIV purified by double banding" in sucrose density gradients. By comparing the amino-acid sequences of these proteins with Class II histocompatability DR proteins, they concluded that "the DR alpha and beta chains appeared to be identical to the p34-36 and p30-32 proteins respectively" 12 .

The p24/25 protein. Detection of p24 is currently believed to be synonymous with HIV isolation and viraemia. However, apart from a joint publication with Montagnier where they claim that the HIV p24 is unique, Gallo and his colleagues have repeatedly stated that the p24s of HTLV-I and HIV immunologically cross-react ${ }^{13}$.

Genesca et al.$^{14}$ conducted WB assays in 100 ELISA negative samples of healthy blood donors; 20 were found to have HIV bands which did not fulfill the then (1989) criteria used by the blood banks for a positive WB. These were considered as indeterminate WB (WBI) with p24 being the predominant band (70\% of cases). Among the recipients of WBI blood, $36 \%$ were WBI 6 months after transfusion, but so were $42 \%$ of individuals who received WB-negative samples. Both donors and recipients of blood remained healthy. They concluded that WBI patterns "are exceedingly common in randomly selected donors and recipients and such patterns do not correlate with the presence of HIV-1 or the transmission of HIV-1," "most such reactions represent false-positive results" 14 .

Antibodies to p24 have been detected in 1 out of 150 healthy individuals, $13 \%$ of randomly selected otherwise healthy patients with generalized warts, $24 \%$ of patients with cutaneous
T-cell lymphoma and prodrome and $41 \%$ of patients with multiple sclerosis ${ }^{15}$.

Ninety-seven percent of sera from homosexuals with ITP and $94 \%$ of sera from homosexuals with lymphandenopathy or AIDS contain an antibody that reacts with a $25 \mathrm{kD}$ membrane antigen found in platelets from healthy donors and AIDS patients, as well as a $25 \mathrm{kD}$ antigen found in green-monkey kidney cells, human skin fibroblasts, and herpes simplex cultured in monkey kidney cells. This reaction was absent in sera obtained from non-homosexual patients with ITP or nonimmune thrombocytopenic purpura ${ }^{11}$. Conversely, the p24 antigen is not found in all HIV positive or even AIDS patients. In one study, the polymerase chain reaction (PCR) and p24 were used to detect HIV in patients at various CDC stages from asymptomatic to AIDS. p24 was detected in $24 \%$ patients and HIV RNA in $50 \%{ }^{16}$. In another study, "In half of the cases in which a subject had a positive p24 test, the subject later had a negative test without taking any medications that would be expected to affect p24 antigen levels...the test is clinically erratic and should be interpreted very cautiously" 17 .

The p17/18 protein. In addition to the p24 band, the p17/18 band is the most often detected band in WB of healthy blood donors $^{18}$. Sera from AIDS patients bind to a p 18 protein in mitogenically stimulated HIV infected T-cells, but not to uninfected, unstimulated lymphocytes. However, when the lymphocytes are mitogenically stimulated, but uninfected, the AIDS sera bind to a p18 protein in these uninfected lymphocytes ${ }^{19}$.

A monoclonal antibody (MAb) to HIV p18 reacts with dendritic cells in the lymphatic tissues of a variety of patients with a number of non-AIDS related diseases ${ }^{20}$, and the "same pattern of reactivity was present in normal tissue taken from uninfected individuals as in those taken from HIV positive subjects"21. AIDS patients and those at risk have high levels of antibodies to the ubiquitous protein-myosin 22 , which has two subunits of molecular weights 18,000 and 25,000 .

In view of the above, it is difficult to defend the view that the bands $\mathrm{p} 41$ (and thus p160 and p120), p32, p24 or p18 represent specific HIV proteins. Moreover, even if it could be shown that all these proteins are HIV specific, it cannot be assumed that antibodies that react with them are diagnostic of HIV infection.

\section{Standardization of HIV Antlbody Tests}

An antibody test becomes meaningful only when it is standardized, that is, when a given test result has the same meaning in all patients, in all laboratories, in all countries. From the first antigen-antibody reactions performed by Montagnier's ${ }^{4}$ and Gallo's ${ }^{23}$ groups (Figs. 1, 2) it was found that not all of the "HIV proteins" react with all sera from AIDS patients or even sera from the same patients obtained at different times, and that sera from AIDS patients may react with proteins other than those considered to be HIV antigens. Because of these variable reactions, an essential requirement was to establish criteria as to what constitutes a positive WB.

In 1987 the Food and Drug Administration (FDA) licensed a WB kit manufactured by DuPont. The DuPont kit remains the only licensed WB kit and is used by a minority of laboratories. It specifies "extremely stringent" criteria for a positive result namely "specific bands representing three different gene products: p24 (gag), p31 (pol), and an env band, either gp4l, gp 120 or gp 160" (ref. 24).

The American Red Cross defines a positive result as presence of antibodies to at least one gene product from each of the $g a g, p o l$ and $e n v$ genes, without specifying which bands.

The Association of State and Territorial Public Health Laboratory Directors/Department of Defence/CDC consider a WB 


\section{IMAGE \\ UNAVAILABLE \\ FOR COPYRIGHT \\ REASONS}

FIGURE 2. (A) "Lysates of HTLV-III producer" H4 clone cells, derived from the HUT78 cell line immunoprecipitated with various sera. (B) "Lysates of HTLV-III producer" $\mathrm{H} 17$ clone cells also derived from the HUT78 cell line, immunoprecipitated with various sera; (the serum in (B) lane 2 is identical to (A) Lane 4). (C) Lysates of $\mathrm{H} 17$ and $\mathrm{H} 4$ clones (b) "before" and (a) "after infection," immunoprecipitated with serum from a male heterosexual drug user with lymphandenopathy and thrombo-

positive if two out of $\mathrm{p} 24$, gp41 and gp 120/160 are reactive.

The Consortium for Retrovirus Serology Standardization (CRSS) defines a positive WB as the presence of antibodies to at least $\mathrm{p} 24$ or $\mathrm{p} 31 / 32$, and gp41 or gp 120/16025.

For all laboratories, a negative result requires the absence of any and all bands including bands which do not represent "HIV proteins." All other patterns which do not satisfy a given laboratory's criteria for a positive or negative test are regarded as WBI by that laboratory. Thus, in the scientific literature, no strips have been published of a standard positive WB. For example, in the 1984 instruction manual of a WB kit manufacturer, Bio-Rad, which reproduces "Examples of a typical reactive patient serum sample and reaction with a strong, weak and non-reactive control" it is also stated, "This example shows typical reactive patterns only, and is not to be used as a reference for comparisons with results from unknown serum samples... Patient samples may show varying degrees of reactivity with different proteins, thus showing different band development patterns... Each laboratory performing Western Blot testing should develop its own criteria for band interpretation. Alternatively, band interpretation may be left to the clinician." In addition to the obvious problems associated with the lack of standardization, all of the above interpretations possess other difficulties.

When the FDA criteria are used to interpret the WB, less than $50 \%$ of AIDS patients have a positive WB. If the criteria of the CRSS are used, the percentage of AIDS patients testing positive increases to $79 \%$. More importantly, even when the most stringent criteria are used, $10 \%$ of control samples, which include "specimens from blood donor centers," have a positive WB's. As already mentioned, Henderson and his colleagues have shown that $\mathrm{p} 31 / 32$ is a non-HIV protein. Pinter and his colleagues have shown that p160 and p120 are oligomers of gp4l. They have also shown that the WB pattern obtained is dependent on many factors including temperature and the concentration of sodium dodecyl sulphate used to disrupt the "pure virus," and concluded: "Confusion over the identification of these bands has resulted in incorrect conclusions in experimental studies. Similarly, some clinical specimens may have been identified erroneously as seropositive, on the assumption that these bands reflected specific reactivity against two distinct viral components and fulfilled a criterion for true or probable positivity. The correct identification of these bands will affect the standards to be established for Western Blot positivity:it may necessitate the cytopenia (pre-AIDS). This is the same serum as (B) Lane 5. (D) "Lysates of H4/HTLV-III... cells" (C), or "virus purified from the cells culture fluids", (V), using (I)-same serum as (B) Lane 5; (II)-serum from a patient with pre-AIDS; (III) serum from a patient with AIDS. This is the same serum as (B) Lane 4. Key to sera: (A) AIDS patient; (P) pre-AIDS patient; (h) healthy control; (U) drug user; $(H)$ homosexual control (From reference 5, with permission).

reinterpretation of published results" 26 .

The finding that the $\mathrm{p} 31 / 32$ band represents a cellular protein, and that p120 and p 160 are oligomers of p 41 , reduces the criteria of the CRSS and that of the American Red Cross to two bands, p24 and p41, which according to Burke are "less than perfectly specific" 27 , and reduces the criteria of the Association of State and Territory Public Health Laboratory Directors/ Department of Defence/CDC to p24 and p4l or just p41.

Despite the above evidence, even at present, the p160, p120 and the $p 41$ bands are considered to represent distinct viral envelope glycoproteins. In fact, the current WHO guidelines consider a serum positive for HIV-1 antibodies if "two envelope glycoprotein bands (with or without) other viral specific bands are present on the strip" ${ }^{28}$.

To date, AIDS in Africa is defined on clinical grounds. Recently, the CDC recommended the future inclusion of serological evidence for HIV infection in the African definition of AIDS. The test recommended is $\operatorname{ELISA}^{29}$, which cannot be considered specific. In Russia, in 1990, out of 20,000 positive screening tests "only 112 were confirmed" using the WB as a gold standard. In 1991, of approximately 30,000 positive screening tests, only 66 were confirmed ${ }^{30}$. In the Latin American and Caribbean AIDS definitions the "clinical findings of HIV infection" are confirmed "by antibody testing using ELISA, immunofluoresence or Western blot methods." No criteria are given for WB interpretation ${ }^{31}$.

\section{Reproducibility}

The problems associated with reproducibility may be best illustrated by two examples. Figure 3 represents WB strips of a serum specimen from a patient with AIDS, that was tested by 19 laboratories that participated in the second CRSS conference on WB test standardization ${ }^{25}$. As can be seen, the band pattern obtained with one and the same serum, varies from laboratory to laboratory, although all laboratories reported this specimen as positive. The Transfusion Safety Study (TSS) Group in the USA submitted approximately 100 patient samples weekly for WB testing to three reference laboratories over three separate periods of several months. With the 100 patient samples, they submitted aliquots from four quality control (QC) plasmas, two positive and two negative. HIV positivity or negativity "was based on the collective experience with each plasma using: (1) licensed EIA systems of five manufacturers, (2) an immunofluoresence assay, 
(3) IB in four reference laboratories, and (4) a radioimmunopreciptation assay in an additional laboratory." (EIA =ELISA; IB $=$ WB). The samples were then sent to reference laboratories which were aware of quality control testing, but "the labels and codes did not permit identification of the QC specimens as such or linkage to previous QC specimens." $\mathrm{QC} 1 \#(+)$ was submitted 40 times to laboratory A, 5 times to laboratory B and 45 times to laboratory C. A reported the following band patterns: p24, p32 and gp41/120, 7 times; p24, gp41/120, 28 times; p24 only, 5 times. B reported: p24, p32, gp41/120, 4 times; p32, gp41/120, on one bccasion. C reported: p24, p32, gp41/120, 26 times; p24, gp41/120, 10 times; p24, p32, twice; p24 only, 5 times; "others," once; no bands, once.

QC\#2(+) was sent a total of 89 times to the three laboratories and was reported: p24, p32, gp41/120, 64 times; p24, gp41/120, 19 times; p24, p32, once; p32, p41/gp120, 4 times; no bands, once.

A total of 101 aliquots of the two quality control negative samples QC\#3(-) and QC\#4(-) were sent to the three laboratories. These were reported: no bands, 67 times; "other" bands, 13 times; gp4l only, once; p24 only, 18 times; p24, p32, gp41/ 120 , twice.

A special panel of QC samples was sent to laboratories B, $C$ and an additional laboratory $D$. The panel consisted of three aliquots of each of eight samples, including batches QC\#1(+), QC\#2(+), QC\#3(-) and QC\#4(-). Discussing the latter results the authors state: “Only Laboratory C's reports with the panel were consistent with the data accrued from all other evaluation of reactivity... Laboratory B reported the three aliquots of QC\#1(+) as respectively positive on the basis of three bands (gp41, p55 and p65), indeterminate on the basis of a single band (gp41), and negative (no bands observed). In addition, all three aliquots of QC $\$ 6(-)$ were considered indeterminate because only a single band (gp4l) was seen. Laboratory D reported one aliquot of QC\#6(-) as positive (p15, p24, p32, gp41, p65) and the other two aliquots as negative (no bands observed). It also reported a band at p55 for all three aliquots of QC $\$ 3(-) " 32$.

In considering the results detailed above, one must bear in mind that they occurred in Reference Laboratories, that is, first class laboratories which constitute only a small number of the total number of laboratories which perform WB testing in the USA. In addition, many laboratories continue to use unlicensed WB kits because of cost and the "stringent criteria required for interpreting the licensed test" ${ }^{33}$.

\section{Specificity of the HIV Antlbody Tests}

The task of authenticating a new diagnostic test in clinical medicine requires an alternative, independent method of establishing the presence of the condition for which the test is to be employed. This method, often referred to as the gold standard, is a crucial sine qua non, and represents the tenet upon which rests the scientific proof of validity. The only possible gold standard for the HIV antibody tests is the human immunodeficiency virus itself. The clinical syndrome and the decrease in T4 cells cannot be considered a gold standard. Although HIV has never been used as a gold standard there is general consensus that proof of the specificity of the HIV antibody tests is firmly established. For the ELISA, Gallo's best figures, obtained from AIDS patients and 297 healthy blood donors, were $97.7 \%$ sensitivity and $92.6 \%$ specificity assuming borderline tests as positive, and using the clinical syndrome as gold standard ${ }^{34}$.

Burke and his colleagues from the Walter Reed Army Institute in the USA are credited as having most thoroughly researched the problem of defining HIV antibody specificity in a large population and their data are widely believed to represent the current state of the art ${ }^{35}$. Burke et al. ${ }^{36}$ tested a highly selected healthy subpopulation of 135,187 individuals chosen for a very low prevalence of HIV infection-1/10th that of a much larger pool of applicants (1.2 million), for US military service. All applicants were screened with an initial ELISA, and all reactive ELISA tests were repeated. An initial WB was performed and, if diagnostic or reactive, a second WB was done on another fresh blood specimen. Initially the criteria for a positive and diagnostic WB were the "presence of a band at $41 \mathrm{kD}$, a combination of the bands 24 and 55kD, or both. Beginning in May 1987, the method of preparing blot strips was modified so that antibodies to gp 120 and gp 160 could be detected reproducibly, and criteria for a reactive and diagnostic blot pattern were changed to those of the Association of State and Territorial Public Health Laboratory Directors." A positive WB was diagnosed if and only if the first and second serum samples were diagnostic on WB. All of the diagnostic WB samples were then assayed with four other antibody tests. A WB was considered "true positive if all four assays on all available serum samples from an applicant were reactive and diagnostic," but was considered "false positive if all four assays on all available serum samples from an applicant were non-reactive, non-diagnostic or both." From the 135,187 applicants, there were 16 positive tests. In one of these, the serum was unavailable for further testing and one applicant declined to provide a second sample. Serum from 27 of the 29 samples from the 15 applicants found positive were tested by the four other antibody tests. Fourteen samples were found positive by all four assays and all four were negative for one applicant. From this Burke and his associates calculated the false positive rate as 1 in 135,187 or $0.0007 \%$.

They also speculated on the implications that this data might hold for their entire population of 1.2 million applicants. They calculated the overall prevalence of 1.48 per 1000 in the entire pool as equivalent to 200 per 135,187 . Assuming that the false positive rate is the same for the whole population, they estimated that since there will be 200 true positive tests per 135,187 persons of which only one will be a false positive then the "predictive value of a positive diagnosis in this program is $99.5 \%$," with "a specificity of roughly 99.9993 percent" 35.36 . Much of this reasoning is open to criticism: (1) There is no gold standard for defining HIV infection. Testing the positive WB in the 15 remaining applicants against four other antibody tests does not enable an independent establishment of "true" HIV infection as they are the same test. (2) They define the true positive tests as samples which repeatedly test positive in four similar tests, and the false positive tests as samples which repeatedly test negative in four similar tests. The number of samples tested and the repeats is arbitrary. It would be impossible to say what the outcome would be if, for example, the ELISA tests were repeated three instead of two times, or if the samples which tested negative in the first ELISA were tested again with another ELISA or WB. There are well documented reports in which the ELISA is negative and the WB positive ${ }^{37}$. They further define the false positive rate as the number of false positive results divided by the number of samples tested. These definitions bear no resemblance to those described in standard texts $^{38}$. The correct definitions are: A true positive is a positive test occuring in an individual who is HIV infected as defined by an independent gold standard; a false positive is a positive test which occurs in an individual who, by application of the gold standard, does not have HIV infection, (but is not necessarily healthy), and the false positive rate is the number of false positive tests as a fraction of all positive tests, both true and false positive.

Further, the premises of Burke et al. are quite opposite to those of Gallo et al. where all positive test results in healthy 
individuals are regarded as false positive. Based on Gallo and his associates' premises, we must regard all sixteen cases as false positives as there is no compelling reason to view healthy military applicants as significantly different from healthy blood donors. Moreover, extrapolation to the entire 1.2 million applicants is invalid. This extrapolation can only be done if the 135,187 applicants were randomly selected from the entire pool, which they were not. Additionally, their stated figure of $99.5 \%$ positive predictor value is impossible to arrive at without knowledge of the sensitivity of the WB test and the prevalence of true HIV infection ${ }^{38}$, even if the specificity and the extrapolation were correct.

Finally, it is impossible to define specificity, sensitivity and predictive value with the algorithm used by Burke and his associates. The best they can do with their algorithm is to determine the reproducibility of ELISA and WB. In this regard, in the larger study of 1.2 million healthy military applicants, approximately $1 \%$ of all initial ELISAs were positive of which $50 \%$ were subsequently negative; $30-40 \%$ of first WB were positive and $96 \%$ of second WB were positive. In other words Burke's larger study reveals 6,000 individuals with an initially positive but subsequently negative ELISA, 4,000 individuals with two positive ELISA's followed by a negative WB, and 80 individuals with two positive ELISA's, an initially positive WB and a negative repeat WB.

This cannot be regarded as a trivial problem since several thousand healthy individuals have antibodies that react with "HIV proteins" but who are ultimately deemed not to be HIV infected. Even in the best laboratories, 80 of Burke's healthy applicants would be diagnosed as HIV infected since only one WB is performed.

The problem becomes even more serious when one realizes that by September 1987 (by which time, based on the antibody tests, a causal relationship between HIV and AIDS was generally accepted) a single positive ELISA or a positive WB, one band (either p24 or p41) was sufficient to confirm HIV infection. At present, the general opinion is that the ELISA tests have a "sensitivity and specificity of over $98 \%$, many approaching $100 \% " 24$, and the CDC AIDS definition "accepts a reactive screening test for HIV antibody without a confirmation by a supplemental test because a repeatedly reactive screening test result, in combination with an indicator disease, is highly indicative of true HIV disease" ${ }^{39}$ (screening test=ELISA).

Burke et al., like Gallo et al., determined specificity without reference to sick individuals. The definition of specificity requires that the test is evaluated in persons who do not have the disease which is under scrutiny, including sick individuals who have other diseases where antibodies, some of which may interact with HIV antigens, may be produced for other reasons. The specificity of the HIV antibody tests must be determined by testing individuals who are immunosuppressed and/or who have symptoms and clinical signs similar to AIDS, but who are not considered to have AIDS or HIV infection. This point is well illustrated by the serological tests for syphilis. A healthy person who is not infected with Treponema pallidum would very seldom test positive (false positive). However several authors attest to the presence in various unrelated disorders of biological false positive tests to syphilis (BFPS), which may occur in patients with auto-immune haemolytic anaemia, systemic lupus erythematosus (SLE), idiopathic thrombocytopenic purpura, leprosy and in drug addicts. More than $20 \%$ of drug addicts test positive and have the highest incidence of BFPS' ${ }^{40}$. Persons with BFPS were also found "to have a high frequency of other serological abnormalities including anti-nuclear factors, autoantibodies, and alterations of gamma globulin." This led researchers to conclude that "a BFP reaction often is a marker for an unidenti- fied disorder of the immune system that predisposes to autoimmune diseases" 40 . It is of significance that a high proportion (14\%) of AIDS patients were also found to have false positive syphilis serology ${ }^{4}$.

At least two groups of researchers raised the possibility that the HIV antibody test in Africans and IV users may also be a BFP reaction. Jaffe et $\mathrm{al}^{42}$ tested 1129 serum samples from IV drug users and 89 controls from non-users. All samples were collected during 1971-1972 and tested by two commercial ELISAs and WB. Seventeen of the samples from the IV drug users, but not one of the controls was found positive. They concluded: "On the basis of our positive Western Blot data, it appears that parenteral drug users may have been exposed to HTLV-III or a related virus as early as 1971 . An alternative but equally viable explanation is that the HTLV-III seropositivity detected in these specimens represents false positive or nonspecific reactions." Biggar and his colleagues ${ }^{43}$ found that in healthy Africans the probability of finding a positive HIV antibody test increased significantly with increasing immune-complex levels. They concluded "reactivity in both ELISA and Western Blot analysis may be non-specific in Africans....the cause of the non-specificity needs to be clarified in order to determine how they might affect the seroepidemiology of retroviruses in areas other than Africa, such as the Caribbean and Japan."

That a positive WB in all individuals may represent a BFP reaction is suggested by evidence from both retrovirology in general and HIV antibody testing in particular. It is known that all antibodies including MAbs are capable of reacting with immunizing antigens as well as other self and non-self components ${ }^{44.45}$. In relation to retroviruses, the scientific literature abounds with data which show the widespread presence of nonspecific interactions between retroviral antigens and unrelated antibodies. Much of this work has appeared as a result of the search for a viral origin of animal and human neoplasms ${ }^{46} \leqslant 1$.

In drug addicts there is a strong association between high serum globulin levels and a positive HIV antibody test and this was the "only variable which remained significant in a logistic regression model"s2. In children, using WB as a gold standard, hyperglobulinaemia identified HIV infected children with a specificity of $97 \%^{53}$. Sixty-three sera obtained from 23 patients before and immediately after immunoglobulin infusion were tested for HIV antibodies using WB. Of the 63 sera, $52(83 \%)$ were found positive. "Several samples tested in an HTLV-III p24 radioimmunoassay were also positive. The amount of antibody detected was greatest immediately after infusion and decreased between infusions" ${ }^{\prime 4}$. An individual was given six $5 \mathrm{ml}$ injections of donated $\mathrm{Rh}^{+}$serum, administered at 4 day intervals. "The donor serum was shown to be negative on HIV antibody and antigen ELISA, so was blood taken from his wife and child." "Blood taken after the first immunization was shown to be negative on HIV antibody ELISA and immunoblot assay. After the second immunization a weak signal on ELISA, slightly above the cut-off level, was monitored. After the third immunization the signal was strong and immunoblot revealed distinct interaction with p 17 and p55 proteins. An even stronger signal was monitored after the fifth immunization. Interaction with p17, p31, gp41, p55 and some other proteins was evident"ss.

Since individuals from the main AIDS risk groups, that is, gay men, drug users and haemophiliacs are exposed to many foreign substances such as semen, drugs, factor VIII, blood and blood components; and individuals belonging to the above groups commonly develop infections unrelated to HIV; one would expect these individuals to have high levels of antibodies directed against antigens other than HIV. In fact individuals with AIDS, AIDS-related complex (ARC) and those at risk, have 
circulating immune complexes, rheumatoid factor, anti-cardiolipin, anti-nuclear factor, anti-cellular, anti-platelet, anti-red cell, anti-actin, anti-DNA, anti-tubulin, anti-thyroglobulin, anti-albumin, anti-myosin, anti-trinitrophenyl and anti-thymo$\sin$ antibodies 22.56 . Anti-lymphocyte auto-antibodies have been found in $87 \%$ of HIV + patients, and their levels correlate with clinical status $^{57.58}$. Unlike normal sera, $37 \%$ of HIV + sera were found positive for Type-D retroviruses ${ }^{59}$, whereas HIV is thought to be a Lentivirus.

It is also known that serum IgG levels are higher in AfricanAmerican blood donors than in Caucasians ${ }^{60}$, that some risk groups, drug users and gay men are exposed to high levels of mitogenic agents, semen and nitrites ${ }^{61.62}$, and that animals treated with such agents develop antibodies which react with retroviral antigens ${ }^{63}$. That a positive HIV antibody test may be the result of antigenic stimulation, other than HIV, is further supported by the following data: (1) HIV is thought to be transmitted by infected needles, yet a higher percentage of prostitutes who use oral drugs ( $84 \%)$, than IV $(46 \%)$, test positive ${ }^{* 4}$. (2) "Mice of the autoimmune strains MRL-lpr/lpr and MRL $+1+$ made antibodies against gp 120." Mice that have been exposed to T-lymphocytes from another murine strain were shown to make antibodies against gp120 and p24 of HIV ${ }^{65}$. (3) Recipients of negative blood seroconvert and develop AIDS while the donors remain healthy and seronegative ${ }^{66}$. (4) In healthy individuals, partners of HIV positive individuals, organ transplant recipients and patients with SLE, a positive WB may revert to negative when exposure to semen, immunosuppressive therapy or clinical improvement occurs ${ }^{67-69}$. (5) While the frequency of positive HIV antibody tests in healthy blood donors and military applicants is low, patients with tuberculosis (TB), including those with TB localized to the lungs, both in the USA ${ }^{70}$ and Africa ${ }^{71}$, have a high frequency, up to $50 \%$, of positive WBs. In the $\mathrm{USA}^{72}$ (26 hospitals studied), patients who are not at risk of developing AIDS, and who do not have any infectious diseases, have a high rate of positive WB, (1.3\% to $7.8 \%)$. The above data may be interpreted either as proof that HIV is spreading to the heterosexual population or that the HIV antibody tests are non-specific. That the latter is the case is suggested by the fact that by 1988, in the USA, only approximately 66 white males were reported to have had "heterosexually acquired AIDS"73. By 1992 in New York only 11 men were reported to have AIDS due to heterosexual infection ${ }^{74}$.

Rodriguez and his colleagues ${ }^{75}$ found that Amazonian Indians who have no contact with individuals outside their tribes and have no AIDS have a 3.3-13.3\% HIV WB seropositivity rate depending on the tribe studied. In another study ${ }^{76}$ they found that $25 \%-41 \%$ of Venezuelan malaria patients had a positive WB, but no AIDS. The above data means either that HIV is not causing AIDS "even in the presence of the severe immunoregulatory disturbances characteristic of acute malaria," as Rodriguez et al. concluded, or the HIV antibody tests are non-specific.

The problems associated with the specificity of the WB could be avoided by use of the only suitable gold standard, HIV isolation. To date this has not been done and based on the problems associated with HIV isolation, it may not even be feasible.

\section{HIV lsolation}

Virus isolation can be used as a gold standard only if it provides conclusive genetic, virological and molecular evidence for the existence of a unique virus. For retroviruses, as a first step towards this goal one must find particles with morphological characteristics similar to other retroviruses, and demonstrate that these particles have a unique set of structural components

\section{IMAGE \\ UNAVAILABLE \\ FOR COPYRIGHT REASONS}

FIGURE 3. WB of one and the same serum specimen tested by 19 laboratories (From reference 25, with permission).

including RNA and proteins, which belong only to these particles and to no other entity.

Peyton Rous ${ }^{77}$ is credited with the discovery and isolation of the first retrovirus. In 1911 he was able to repeatedly induce tumours in a particular breed of chickens by means of tumour derived, cell free filtrates. Rous contemplated that either a "minute parasitic organism" or "a chemical stimulant" might form the basis of his observations; nevertheless, the tumour inducing filtrates became known as "filterable viruses" or oncoviruses. In the 1950s, in animal cultures and in fresh tissue, especially tumour tissue, particles later attributed to retroviruses were readily detectable with electron-microscopy (EM). In 1970 , the enzyme reverse transcriptase (RT) which transcribes RNA into DNA, was discovered in oncoviruses. Because of this, in the 1970's, oncoviruses became known as retrovinuses. In the preceding decade, density gradient centrifugation was introduced to separate and isolate sub-cellular particles including viruses. Because some cellular constituents were found to have the same buoyant density as viruses, when viruses were isolated from cell cultures, the best results could be obtained with supernatant fluids which had high viral concentration and had low cellular contaminants. This was best satisfied by non-cytopathic viruses and by culture conditions which maintained maximum cellular viability. Most retroviruses (exceptions are the so-called animal immunodeficiency viruses) satisfy the above conditions. Taking advantage of the above retroviral properties, by repeated suspension and sedimentation in sucrose density gradients, one could obtain, at a density of $1.16 \mathrm{gm} / \mathrm{ml}$, a relatively pure concentration of retroviral particles-that is, obtain particles, separate from everything else, and thus isolate them ${ }^{78}$. Nonetheless, as many eminent retrovirologists point out, contamination of the viral preparation with vinus-like particles which contain RT, but could be nothing more than "cellular fragments," microsomes from disrupted cells, "membraneous vesicles which may enclose other cellular constituents including nucleic acids," especially when "inadvertent lysis of cells" was induced, could not be avoided ${ }^{79-81}$. Because of this, to prove that the material which banded at $1.16 \mathrm{gm} / \mathrm{ml}$ contained nothing else but particles with "no apparent differences in physical appearances," and that the particles were indeed retroviruses, every.retrovirus preparation was further analyzed using electron microscopy (EM) for virus count, morphology and purity; RT activity, viral and 


\section{IMAGE UNAVAILABLE FOR COPYRIGHT REASONS}

FIGURE 4. Structural model of HIV-1 (From reference 107, with permission).

cellular RNA, total protein, gel analyses of viral and host proteins and nucleic acids to establish biochemical criteria, and were assayed biologically for infectivity in vivo and in vitro ${ }^{78.82}$.

In most retroviral cultures the particle concentration is reasonably high $\left(10^{4}-10^{5}\right.$ infectious units $\left./ \mathrm{ml}\right)$, but in primary AIDS cultures/co-cultures the particle concentration is so low that both Gallo's and Montagnier's groups had difficulty in detecting them. Unlike other animal retroviruses, HIV is considered to be cytopathic. If this is so, then cell culture supernatants will contain many cellular constituents. Further, if, as has been recently proposed, "a single unique mechanism," HIV induced apoptosis, can account for T4 cell death ${ }^{83}$, then the supernatant must also contain apoptotic bodies, that is, membrane bound cellular fragments which, (like many retroviruses), bud from the cell surface. Since the size and composition (some contain pyknotic chromatin) of the apoptotic bodies vary widely ${ }^{84}$, one would expect that some of these fragments will also band at $1.16 \mathrm{gm} / \mathrm{ml}$. It is significant that the AIDS cultures/co-cultures do not have maximum viability, and most if not all claims of "HIV isolation" have been from cellular lysates. Most importantly, an extensive search of the AIDS literature revealed no electron micrographs of the material which bands at $1.16 \mathrm{gm} / \mathrm{ml}$. All electron micrographs are of particles found in cell cultures. Thus it is impossible to know whether the material which bands at $1.16 \mathrm{gm} / \mathrm{ml}$ (the "pure HIV particles") contains any such particles whatsoever, and if such particles are present, what is their purity.

The available evidence in fact indicates that only about $20 \%$ of the proteins which band at $1.16 \mathrm{gm} / \mathrm{ml}$ are "HIV proteins," the rest are cellular, including beta- 2 microglobulin and HLADR proteins $(4.4 \%)^{12.85}$. Thus, even if particles are present at $1.16 \mathrm{gm} / \mathrm{ml}$ and all the proteins assumed to be HIV are embodied in the HIV particle, the material which bands at $1.16 \mathrm{gm} / \mathrm{ml}$ cannot be considered "pure HIV." Conversely, "Much of the viral protein secreted from HIV-infected cells is non-particulate, and the proportion of (for example) p24 in virions is a function of the viral genotype and the age of the culture. In extreme cases, less than one percent of the total p24 and gp 120 present [in the culture] is in virions" ${ }^{86}$. In fact, p24 is released from "infected cells independently of infectious virus particles" and $\mathrm{RT}^{87,88}$.

It must be pointed out that the terms in the AIDS literature "HIV," "HIV isolation," "pure particles," "virus particles," "virions" and "infectious particles" have a variety of meanings and include all of the following, but most often without proof of the presence of a particle: "RNA wrapped in protein" 89 , material from the cell culture supernatants which passes through cell tight filters but through which organisms such as Mycoplasmas may pass ${ }^{90}$, the pellet obtained by simple ultracentrifugation of the culture supernatant ${ }^{91}$, and recently, very often, detection in AIDS cultures of $\mathrm{p} 24^{92.93}$.

In the first report of "HIV isolation," Montagnier's group detected in a mitogenically stimulated culture derived from a lymph node biopsy of a gay man with lymphadenopathy, "a transient," "reverse transcriptase activity." In mitogenically stimulated umbilical cord lymphocytes cultured with supernatant from the above cultures, they reported type- $C$ retroviral particles (RVP) in the cultures and RT and antigens which reacted with pre-AIDS sera in the material which banded at $1.16 \mathrm{gm} / \mathrm{ml}^{4}$. Gallo's group did not consider the detection of the above as representing "true isolation," "...the virus has not been transmitted to a permanently growing cell line for true isolation and therefore has been difficult to obtain in quantity" 94 . But, although Gallo's group used a permanent cell line for "HIV isolation," they reported nothing more than the same phenomena as Montagnier's group. Nevertheless, at present, the detection of the above phenomena are considered to represent "true isolation" and their finding in a similar culture is regarded as proof of infectivity. Isolation, however, is defined as separating the virus from everything else and not detection of some phenomena attributed to (RT, antibody/antigen reactions [WB]), or similar to it (particles). Such phenomena can only be used for viral detection, and even then, if and only if, they have been proved to be specific for the virus.

Reverse transcriptase. In all HIV research, the copying of the template-primer $A_{n} \cdot d T_{\overline{15}}$ when incubated with the supernatant or the material which bands at $1.16 \mathrm{gm} / \mathrm{ml}$ from the AIDS cultures/co-cultures is considered proof of HIV RT activity. In many instances this activity is considered synonymous with "HIV isolation" and is used to quantify the virus. However, the same template-primer is also copied when incubated with material which bands at $1.16 \mathrm{gm} / \mathrm{ml}$ from leukaemic T-cell cultures ${ }^{95}$ and normal uninfected spermatozoa ${ }^{96}$. Both $A_{n} \cdot d_{T}$ and $C_{n} \cdot d_{G_{15}}$ are copied by material which bands at $1.16 \mathrm{gm} / \mathrm{ml}$ originating from normal uninfected but mitogenically stimulated lymphocytes $^{95.97}$, and $\mathrm{A}_{\mathrm{n}} \cdot \mathrm{dT}_{\overline{15}}$ is copied not only by RT but also by two (beta and gamma) of the three cellular DNA polymerases. In fact, in 1975, an International Conference on Eukaryotic DNA polymerases defined DNA polymerase gamma as the cellular enzyme which "copies $A_{n} \cdot d_{15}$ with high efficiency but does not copy DNA well"98. Thus, the copying of the template-primer $\mathrm{A}_{\mathrm{n}} \cdot \mathrm{dT} \mathrm{T}_{\mathrm{15}}$, cannot be considered synonymous with the presence of HIV RT.

Particle detection. Retroviruses are enveloped infectious particles about $100-120 \mathrm{nM}$ in diameter with a core comprising a protein shell and a ribonucleoprotein complex. Retroviruses are classified into three Subfamilies-Spumavirinae, Lentivirinae and Oncovirinae. Retroviruses belonging to the latter Subfamily are divided into Type-A, B, C and D particles. Nevertheless, some of the best known retrovirologists do not consider the finding of "virus-like particles morphologically and biochemically resembling," retroviruses, proof of the existence of such viruses ${ }^{99}$. In the 1970s, such particles were frequently observed in human leukaemic tissues ${ }^{99}$, cultures of embryonic tissues ${ }^{100,101}$, and "in the majority, if not all, of human placentas" 102 .

The particles detected in AIDS cultures/co-cultures are considered by all AIDS researchers as being HIV. There is, however, no agreement as to which Genus or even Subfamily of retroviruses they belong. Sometimes agreement in not found even within the same laboratory. For example, Montagnier's 
group initially reported HIV as a Type-C oncovirus ${ }^{4}$, then a Type-D oncovirus ${ }^{104}$ and subsequently as belonging to a different Subfamily of retroviruses-Lentivirinae ${ }^{105}$. Moreover, the "HIV particles" in monocytes differ from both the Type-C oncoviruses and lentiviruses ${ }^{106}$.

Gelderblom et al. put forward an HIV model (Fig. 4) which has a well defined morphology and composition, including surface knobs made of $\mathrm{pl} 20$, a protein considered to play a crucial role in cytopathogenesis and to be indispensable for HIV infectivity ${ }^{107}$. The model has been accepted and is well known. However, the same group using EM and immune electronmicroscopy has shown that knobs are found only in immature (budding) particles, which are "very rarely observed," and aro seen only "on metabolically impaired cells"2.108 and that mature particles are "handly, if at all, labelled" by AIDS and ARC sera. Immature particles are "highly labelled," but so is the rest of the cell from which they are budding, which "might be due to the fact that natural immune sera are indeed polyspecific"2.109, and like sera, antibodies to 120 react preferentially with immature particles ${ }^{107}$. MAbs against gag proteins label the mature particles, but they also label HIV-2 particles and simian immunodeficiency virus particles ${ }^{110}$. In the HIV particles, including its membrane, they'"I (as well as others ${ }^{\prime 2}$ ) detected many cellular proteins, but with the possible exception of the "lateral bodies," these proteins are not included in the idealized HIV model.

T-cell and monocyte "HIV infected cultures" contain in addition to particles with the morphologies attributed to HIV, many other "viral particles" unlike any of the "HIV particles" $106,111,113,114$. Non-HIV infected H9 cells, from which most of the published EM have originated, as well as other cells used for "HIV isolation," CEM, C8166, EBV transformed B-cells, and cord blood lymphocytes, express budding virus-like particles albeit they are somewhat different from particles accepted as $\mathrm{HIV}^{115}$. The above data raise questions regarding the origin and role of both the "non-HIV particles" and "HIV particles," and questions as to which of these particles band at $1.16 \mathrm{gm} / \mathrm{ml}$. Budding and mature type-C particles appear in metabolically impaired but non-HIV infected lymphoma cells ${ }^{116}$, and "retroviral particles" antigenically related to HIV have been found in cultures of salivary gland extracts from patients with Sjorgen's syndrome ${ }^{117}$.

The independent finding of "virus-like" particles in the lymph nodes of AIDS patients with lymphadenopathy"18 and of proteins in the lymph nodes which reacted with MAbs to p55, p24 and p18 (ref. 119) were interpreted as proof that the "viruslike particles" were HIV. However, MAbs to p18 react with lymphatic tissues of patients who suffer from a number of nonAIDS related diseases, and also healthy individuals ${ }^{20.21}$. In the lymph nodes of patients with AIDS-related persistent generalized lymphadenopathy, in addition to the "HIV particles," particles unlike those of HIV are also found"20, and most importantly, in the only EM study ${ }^{121}$, either in vivo or in vitro, in which suitable controls were used and in which extensive blind examination of controls and test material was performed, virus particles indistinguishable from HIV were found in a variety of non-HIV associated reactive lymphadenopathies leading the authors to conclude: "The presence of such particles do not, by themselves indicate infection with HIV."

Comments on "isolation." The cell line most often used in AIDS research is the leukaemic cell line H9. H9 is a clone of HUT78, which was derived from a patient with adult T-cell leukaemia. Since the causative agent of this leukaemia is accepted to be HTLV-I, another exogenous retrovirus, the H9 cultures should have both RT and retroviral particles even in the absence of HIV. Because about 25\% of AIDS patients have antibodies to HTLV-I (ref. 51 ), about $25 \%$ of cultures should have in addition to particles and RT, a positive WB to HTLV-I. However, since the proteins from HIV and HTLV-I share the same molecular weights, the HTLV-I WB bands will appear to be positive for HIV.

A more direct problem associated with the use of "HIV isolation" as a gold standard is the fact that, irrespective of the various phenomena accepted by AIDS researchers as representing "HIV isolation," and despite the fact that no effort has been spared, it is not possible to "isolate HIV" from all antibody positive patients. The success rate varies between $17 \%$ and $80 \%{ }^{92.93 .123}$. Conversely, when the same effort is made, HIV can be isolated from some non-AIDS seronegative patients, and even from normal seronegative individuals at no risk for HIV infection" 124,125 . With a more recent method used for "HIV isolation," detection of p24 in cultures with whole unfractionated blood $^{126.127}$, positive results have been reported in $49 / 60(82 \%)$ of "presumably uninfected, but serologically indeterminate" individuals and in 5/5 "seronegative blood donors" 128 .

As far back as 1988, researchers at the CDC in the USA realized that no correlation exists between "HIV isolation" and a positive antibody test (which they call documented infection), and more importantly, between "HIV isolation" in vitro and its presence in vivo-"correlation between these two methods is limited; they are inconsistent, in that virus cannot be detected in every person with a documented infection. Furthermore, the culture technique determines the ability of infected cells to produce virus in vitro but does not necessarily indicate the status of virus expression in vivo"129.

\section{Genomic Investigations}

In the decades following Rous' initial experiments, he as well as other researchers performed similar investigations with several animal species. Although neoplasia could be induced by injection of filtrates from tumor tissues, (infectious retroviruses, exogenous retroviruses), no epidemiological evidence existed to suggest an infectious origin of cancer. In 1939 Andrews "speculated on the possible activation of latent viral infectious particles in cancerous tissues," and in 1948 Darlington postulated "that such viruses [endogenous viruses] could arise from cellular genetic elements which he named proviruses" 1 . In the 1950 s and 1960 s the following experimental evidence was considered proof of the proviral hypothesis. Healthy animals in which no complete virus could be detected had viral antigens similar to those of exogenous virus, and DNA genomes or partial genomes of the infectious retroviruses were found to be integrated into the genomes of normal non-virus producing cells. "Final proof came with the isolation of infectious viruses from uninfected cells." Healthy non-virus producing cells when cultured were found to spontaneously produce viruses ${ }^{80}$. Their appearance and yield could be increased a millionfold by mitogenic stimulation $^{130}$, co-cultivation techniques ${ }^{131}$, and cultivation of cells with supernatant from non-viral producing cultures ${ }^{132}$. (Note: For HIV isolation, mitogenic stimulation is an absolute requirement, and in most cases all of the above are employed).

It is generally accepted that "one of the most striking features that distinguishes retroviruses from all other animal viruses is the presence, in the chromosomes of normal uninfected cells, of genomes closely related to, or identical with, those of infectious viruses"

Depending on conditions, the provirus genome remains unexpressed or part or all of it may be expressed. The latter may or may not lead to the assembly of viral particles (endogenous retrovirus) ${ }^{30}$. In other words, the finding of a viral genome antigens and antibodies to them, is not proof of the presence of infectious particles. Although most of the above reports are from animal experiments, "The human genome carries DNA 
sequences related to endogenous retroviral genomes that are subdivided into families according to sequence homology. Some are present in only a few copies, whereas others are present in hundreds to thousands of copies"' 13 . Animal data also show that new retroviruses may arise by phenotypic mixing as well as by genetic recombination and deletion. When a cell contains two proviruses, progeny may be found that possess the genome of one but the structural proteins of either (or both) viruses present. Conversely, the RNA may be viral but at least some of the proteins may be cellular. In other instances, the particles do not have a genome at all, or one or more genes are missing (genetically defective viruses). The genetic mixing can be between viral genomes or between viral and cellular genes $s^{80.134}$ and new retroviral genomes may arise by rearrangement of cellular DNA caused by many factors including pathogenic processes ${ }^{135.136}$, a view that proposes retroviruses as an effect and not the cause of disease. The time and appearance of the viral genome "may be millions of years in germ-line cells and days in somatic cells" In addition, since the retroviral replicative cycle "involves three distinct steps: reverse transcription, DNA polymerization, and the synthesis of RNA from a DNA template (transcription), and errors made by the polymerase enzyme during the first and the third steps are not subjected to proof reading, the result being pronounced sequence variability" 137 . Hence, as early as 1973 , it was concluded that the above phenomena "will prove a stumbling block to any genetic analysis of RNA tumour viruses" 178 (RNA tumour viruses=retrovirus). The data on the HIV genome has not altered the above prediction and shows that many problems may exist with the use of genomic studies in efforts to prove infection of AIDS patients with a unique exogenous retrovirus, HIV. Some of these problems can be summarized as follows:

No two HIV genomes are the same. No two identical HIV have been isolated even from the same person. In one case where two sequential isolates were made 16 months apart, none of the provirus in the first isolate was found in the second ${ }^{1.4}$, leading one HIV researcher to conclude "The data imply that there is no such thing as an [AIDS virus] isolate"1+1). From the same person at a given time more than one HIV can be isolated ${ }^{141.142}$. Many, if not all of the proviruses detected in vivo and in vitro are defective $e^{133}$. In one and the same patient, the genomic data in monocytes differs from that in T-lymphocytes ${ }^{144}$. The genetic data obtained in vitro do not correlate with the data obtained in vivo ${ }^{145}$. "To culture is to disturb." The type of virus isolated is determined by the cell types used for HIV isolation $^{142.146}$.

HIV sequences cannot be found in all AIDS patients. Gallo and his colleagues, summarizing the first hybridization studies with fresh tissue concluded: "We have previously been able to isolate HTLV-III from peripheral blood or lymph node tissue from most patients with AIDS or ARC" [approximately $50 \%$ of patients referred to by Gallo]. "However, as shown herein, HTLV-III DNA is usually not detected by standard Southern Blotting hybridization of these same tissues and, when it is, the bands are often faint...the lymph node enlargement commonly found in ARC and AIDS patients cannot be due directly to the proliferation of HTLV-III-infected cells...the absence of detectable HTLV-III sequences in Kaposi's sarcoma tissue of AIDS patients suggests that this tumor is not directly induced by infection of each tumor cell with HTLV-III...the observation that HTLV-III sequences are found rarely, if at all, in peripheral blond mononuclear cells, bone marrow, and spleen provides the first direct evidence that these tissues are not heavily or widely infected with HTLV-III in either AIDS or ARC"147. These studies were confirmed by many other researchers.

To improve detection, the polymerase chain reaction (PCR) method was introduced. However, "a striking feature of the results obtained so far" with this method, as with the standard hybridization technique, "is the scarcity or apparent absence of viral DNA in a proportion of patients" $1+8$ and, when viral RNA or DNA is found. the "signal" is very low. For example, HIV is thought to be transmitted primarily by sexual intercourse yet with the PCR the "HIV genome" can be detected in a minority of semen samples $(1 / 25)^{1+4}$. It must be pointed out that a positive PCR cannot be regarded as signifying the presence of the whole HIV genome. With PCR "only small regions may be amplified, a gene at best" ${ }^{\circ: 3}$. Since one does not detect the whole viral genome, and, since most HIV "isolates" to date are defective, detection of part of or a whole gene, or even several genes, cannot be considered synonymous with the whole HIV genome. Furthermore, the PCR is not standardized, and to date there has been only one study in which the reproducibility, sensitivity and specificity of PCR were examined. In this study, the gold standard used was serological status. Specificity was determined by measuring the percentage of negative PCR results in seronegative (ELISA), healthy, low risk individuals (blood donors). The PCR was found not to be reproducible and "false-positive and false negatives results were observed in all laboratories (concordance with serology ranged from $40 \%$ to $100 \%$ ). In addition, the number of positive PCR results did not differ significantly between high- and low-risk seronegatives"'(s).

The positive hybridization results may not be HIV specific. In 1984 when Gallo and his associates conducted their first hybridization studies, they found that when the results were positive, the hybridization bands were "faint," "low signal." The "low signal" was interpreted as proof that HIV infected individuals contain provirus in small numbers of peripheral blood mononuclear cells and at low copy numbers. However, according to Gallo and his associates, "theoretically this low signal intensity could also be explained by presence of a virus distantly homologous to HTLV-III in these cells"1s?.

Data which have come to light since then surggest this theoretical possibility may be a fact. (1) Although it is no longer accepted that HIV is transmitted by insects, in 1986 researchers from the Pastcur Institute found HIV DNA sequences in tsetse flies, black beetles and ant lions in Zaire and the Central African Republic's!. (2) In 1984 Gallo's group reported that the genome of HIV hybridizes with the "structural genes ( $g a g, p o l$, and env) of both HTLV-I and HTLV-II" "s?. Presently available evidence shows that normal human DNA contains retroviral genomic sequences related to HTLV-I and II ${ }^{153.154}$. (3) In 1985 Weiss and his colleagues reported the isolation, from the mitogenically stimulated T-cell cultures of two patients with common variable hypogammaglobulinaemia, a retrovirus which "was clearly related to HTLV-III/LAV;" evidence included positive WB with AIDS sera and hybridization with HIV probes ${ }^{155}$. (4) DNA extracted from thyroid glands from patients with Grave's disease hybridizes with "the entire gag p24 coding region" of HIV ${ }^{156}$. (5) Horowitz et al., "describe the first report of the presence of nucleotide sequences related to HIV-1 in human, chimpanzee and Rhesus monkey DNAs from normal uninfected individuals." They have "demonstrated the presence of a complex family of HIV-1 related sequences" in the above species, and concluded that "Further analysis of members of this family will help determine whether such endogenous sequences contributed to the evolution of HIV-1 via recombination events or whether these elements either directly or through protein products, influence HIV pathogenesis" 15 ?

That the positive hybridization signals may be due to events induced by the oxidative agents (mutagens and mitogens) to which the AIDS risk groups and the cultures are exposed is suggested by the following: A positive PCR reverts to negative 
when exposure to risk factors is discontinued ${ }^{158.159}$, and monocytes from HIV + patients in which no HIV DNA can be detected, even by PCR, become positive for HIV RNA after cocultivation with normal ConA-activated T-cells ${ }^{100}$.

In 1989, and again in 1992, researchers at the Pasteur Institute concluded that "the task of defining HIV infection in molecular terms will be difficult"145.16!. We agree, and based on the arguments and data reviewed here, further conclude that the use of HIV antibody tests as predictive, diagnostic and epidemiological tools for HIV infection needs to be carefully reappraised.

\section{Acknowledgments}

We wish to thank all our colleagues and especially Udo Schüklenk, Barry Page, Bruce Hedland-Thomas, David Causer, Richard Fox, John Peacock, David Prentice, Ronald Hirsch, Patricia Shalala, Keith Jones, Alun Dufty, June Rider Jones, Coronary Barrow, Dorothy Davis, Julian Smith, Mark Strahan, Vincent Turner, Wallace Turner and Graham Drabble for their continued support and assistance. This work is dedicated in memorium to Methodios Papadopulos and Margaret Joan Turner.

\section{Reterences}

1. Ratner, L., Haseltine, W., Patarca, R. P. et al. 1985. Complete nucleotide sequence of the AIDS vinis, HTLV-II. Nature 313:277-284.

2. Hausmann, E. H. S., Gelderblom, H. R., Clapham, P. R. et al. 1987. Detection of HIV envelope specific antibodies by immunoelectron microscopy and correlation with antibody titer and virus neutralizing activity. J. Virol. Meth. 16:125-137.

3. Pinter, A., Honnen, W. J., Tilley, S. A. et al. 1989. Oligomeric structure of gp41, the transmembrane protein of human immunodeficiency vinus type 1 . J. Virol. 63:2674-2679.

4. Barre-Sinoussi, F., Chermann, J. C., Rey, F. et al. 1983. Isolation of a Tlymphotrophic retrovirus from a patient at risk for Acquired Immune Deficiency Syndrome (AIDS). Science 220:868-871

5. Schüpbach, J., Popovic, M. . Gilden, R. V. et al. 1984. Serological analysis of a subgroup of human T-lymphotrophic retroviruses (HTLV-III) associated with AIDS. Science 224:503-505.

6. Damsky, C. H., Sheffield, J. B., Tuszynski, G. P. et al. 1977. Is there a role for actin in virus budding? J. Cell. Biot. 75:593-605.

7. Stanislawsky, L., Mongiat, F., Neto, V. M. et al. 1984. Presence of actin in oncomaviruses. Biochem. Biophys. Res. Com. 118:580-586.

8. Papadopulos-Eleopulos, E., Turner, V. F. and Papadimitriou, J. M. 1992. Oxidative stress, HIV and AIDS. Res. Immunol. 143:145-148.

9. Hinshaw, D. B., Burger, J. M., Beals, T. F. et al. 1991. Actin polymerization in cellular oxidant injury. Arch. Biochem. Biophys. 228:311-316.

10. Bach, M. A., Lewis, D. E., McClure, J. E. et al. 1986. Monoclonal anti-actin antibody recognizes a surface molecule on normal and transformed human B lymphocytes: Expression varies with phase of cell cycle. Cell. Immunol. 98:364-374.

11. Stricker, R. B., Abrams, D. I., Corash, L. et al. 1985. Target platelet antigen in homosexusl men with immune thrombocytopenia. NEJM 313:1375-1380.

12. Henderson, L. E., Sowder, R., Copeland, T. D. et al. 1987. Direct identification of class II histocompatibility DR proteins in preparations of human T-cell lymphotropic virus type III. J. Virol. 61:629-632.

13. Wong-Staal, F. and Gallo, R. C. 1985. Human T-lymphotropic retroviruses. Nature 317:395-403.

14. Genesca, J., Jett, B. W., Epstein, J. S. et al. 1989. What do Western blot indeterminate patterns for Human Immunodeficiency Virus mean in EIAnegative blood donors? Lancet 11 : 1023-1025.

15. Ranki, A., Johansson, E. and Krohn, K. 1988. Interpretation of antibodies reacting solely with human retroviral core proteins. NEJM 318:448-449.

16. Delord, B., Ottmann, M. Schrive, M. H. et al. 1991. HIV-1 expression in 25 infected patients: A comparison of RNA PCR, p24 EIA in plasma and in situ hybridization in mononuclear cells, p. 113. In: Vol. I, Abstracts VII International Conference on AIDS, Florence, Italy.

17. Todak, G., Klein. E., Lange, M. et al. 1991. A clinical appraisal of the p24 antigen test, p. 326. In: Vol. I, Abstracts VII International Conference on AIDS, Florence, Itaily.

18. Courouce, A., Muller, J. and Richand, B. 1986. False-positive Western blot reactions to human immunodeficiency virus in blood donors. Lancet II: $921-922$.

19. Stricker, R. B., McHugh, T. M., Moody, D. J. et al. 1987. An AIDS-related Cytotoxic autoantibody reacts with a specific antigen on stimulated CD4 + T cells. Nature 327:710-713.

20. Chassagne, J., Vereile, P., Fonck, Y. et al. 1986. Detection of the lymphadenopathy-associated virus p18 in cells of patients with lymphoid diseases using a monoclonal antibody. Ann. Inst. Pasteur/Immunot. 137D:403-408.

21. Parravicini, C.L., Klatzmann, D., Jaffray, P. et al. 1988. Monoclonal antibodies to the human immunodeficiency vinus p 18 protein cross-react with normal human tissues. AIDS 2:171-177.

22. Matsiota, P., Chamaret, S., Montagnier, L. et al. 1987. Detection of natura autoantibodies in the serum of anti-HIV positive-individuals. Ann. Inst. Pasteur/Immunol. 138:223-233

23. Popovic, M., Samgadharan, M. G., Read, E. et al. 1984. Detection, isolation, and continuous production of cytopathic retrovinuses (HTLV-III) from patients with AIDS and pre-AIDS. Science 224:497-500.
24. Wilber, J. C. 1991 . New developments in diagnosing infections, p. 1-15. In: AIDS Clinical Review, P. Volbering, M. A. Jacobson (Eds.). Marcel Dekker Inc., New York.

25. Lundberg, G. D. 1988. Serological diagnosis of human immunodeficięncy virus infection by Western blot testing. JAMA 269:674-679.

26. Zolla-Pazner, S., Gorny, M. K. and Honnen, W. J. 1989. Reinterpretation of human immunodeficiency virus Western blot patterns. NEJM 320:1280-1281.

27. Burke, D. S. 1989. Laboratory diagnosis of human immunodeficiency virus infection. Clin. Lab. Med. 9:369-392.

28. Maskill, W. J. and Gust, I. D. 1992 . HIV-1 testing in Australia. Australian Prescriber 15:11-13.

29. DeCock, K. M., Selik, R. M., Soro, B. et al. 1991. AIDS surveillance in Africa: A reappraisal of case definitions. BMJ 303:1185-1189.

30. Voevodin, A. 1992. HIV screening in Russia. Lancet 339:1548.

31. Working Group on AIDS Case Definition 1990. Epidemiol. Bull. 4:9-11

32. Edwards, V. M., Mosley, J. W. and the Transfusion Safety Study Group. 1991 Reproducibility in quality control of protein (Western) immunoblot assay for antibodies to human immunodeficiency virus. Am. J. Clin. Pathol. 91:75-78.

33. CDC. 1989. Interpretation and use of the Western blot assay for serodiagnosis of human immunodeficiency virus type 1 Infections. MMWR 38 No. S-7:1-7.

34. Weiss, S. H., Goedert, J. J., Sarngadharan, M. G. et. al. 1985. Screening test for HTLV-III (AIDS agent) antibodies. JAMA 253:221-225.

35. Weiss, R. and Thier, S. O. 1988. HIV testing is the answer-what's the question? NEJM 319:1010-1012.

36. Burke, D. S., Brundage, J. F., Redfield, R. R. et al. 1988. Measurement of the false positive rate in a screening program for human immunodeficiency virus infections. NEJM 319:961-964.

37. Scarlatti, G. S., Lombardi, V., Plebani, A. et al. 1991. Polymerase chain reaction, virus isolation and antigen assay in HIV-1-antibody-positive mothers and their children. AIDS 5:1173-1178.

38. Griner, P. F., Mayewski, R. J., Mushlin, A. I. et al. 1981. Selection and interpretation of diagnostic tests and procedures. Ann. Int. Med. 94 (Part 2):559-563.

39. CDC. 1987. Revision of the CDC surveillance case definition for acquired immunodeficiency syndrome. JAMA 258:1143-1145.

40. Conley, C. L. and Savarese, D. 1989. Biologic false-positive serologic tests for syphilis and other serologic abnormalities in autoimmune hemolytic anemia and thromobocytopenic purpura. Medicine 68:67-84.

41. Boue, F., Dreyfus, M., Bridley, F. et al. 1990. Lupus anticoagulant and HIV infection: A prospective study. AIDS 4:467-471

42. Jaffe, J. H., Moore, J. D., Cone, E. J. et al. 1986. HTLV-III seropositivity in 1971-1972 parenteral drug abusers - a case of false positives or evidence of viral exposure? NEJM 314:1387-1388.

43. Biggar, R. J., Gigase, P: L., Melbye, M. et al. 1985. ELISA HTLV retrovinus antibody reactivity associaced with malaria and immune complexes in healthy Africans. Lancet II:520-523.

44. Ternynck, T. and Avrameas, S. 1986. Murine natural monoclonal autoantibodies: a study of their polyspecificities and their affinities. Immunol. Rev. 94:99-112.

45. Pateraki, E., Kaklamani, E., Portocalas, K. R. et al. 1986. Autoantibodies in systemic lupus erythematosus and normal subjects. Clin. Rheumatol. 5:338-345

46. Morton, D. L. and Malmgren, R. A. 1968. Human osteosarcomas: immunologic evidence suggesting an associated agent. Science 162:1279-1281

47. Hirshaut, Y., Pei, D. T., Marcove, R. C. et al. 1974. Seroepidemiology of human sarcoma antigen (S1). NEJM 291:1103-1107.

48. Kurth, R., Teich, N. M., Weiss, R. et al. 1977. Natural human antibodies reactive with primate type-C viral antigens. Proc. Natl. Acad. Sci. 74:1237-1241

49. Snyder, H. W. and Fleissner, E. 1980. Specificity of human antibodies to oncovirus glycoproteins: Recognition of antigen by natural antibodies directed against carbohydrate structures. Proc. Natl. Acad. Sci. 77:1622-1626.

50. Barbacid, M. Bolognesi, D. and Aaronson, S. A. 1980. Humans have antibodies capable of recognizing oncoviral glycoproteins: Demonstration that these antibodies are formed in response to cellular modification of glycoproteins rather than as consequence of exposure to virus. Proc. Natl. Acad. Sci. 77: $1617-1621$.

51. Essex, M., Mclane, M. F., Lee, T. H. et al 1983. Antibodies to cell membrane antigens associated with human T-cell leukemia virus in patients with AIDS. Science 220:859-862.

52. Novick, D. M., Des Jarlais, D. C., Kreek, M. J. et al. 1988. Specificity of antibody tests for human immunodeficiency virus in alcohol and parenteral dnug abusers with chronic liver disease. Alcoholism Clin. Exp. Res. 12:687-690.

53. European Collaborative Study. 1991. Children born to women with HIV-1 infection: natural history and risk of transmission. Lancet 337:253-260.

54. Beneviste, R. E., Ochs, H. D., Fischer, S. H. et al. 1986. Screening for antibodies to LAV/HTLV-III in recipients of immunoglobulin preparations. Lancet I: 1090-1092.

55. Burinsky, K. I., Chaplinskes, S. A., Syrnev, V. A. et al. 1988. Reactivity to gag-and env-related sequences in immunoblot assay is not necessarily indicative of HIV infection. AIDS 2:405-406.

56. Calabrese, L. H. 1988. Autoimmune manifestations of human immunodeficiency virus (HIV) infection. Clin. Lab. Med. 8:269-279.

57. Bonara, P., Maggioni, L. and Colombo, G. 1991. Anti-lymphocyte antibodies and progression of disease in HIV infected patients, p. 149. In: Vol. II, VII International Conference on AIDS, Florence, Italy.

58. Tumietto, F., Costigliola, P., Ricchi, E. et al. 1991. Anti-lymphocyte autoantibodies: evaluation and correlation with different stages of HIV infection, p. 149. In: Vol. II. VII International Conference on AIDS, Florence, Italy.

59. Morozor, V. A., Ilyinskii, P. O., Uckert, W. A. et al. 1989. Antibodies to structural and nonstructural gag-coded proteins of type-D retrovinuses in 
60. Lucey, D. R., Hendrix. C. W.. Andrzejewski. C. et al. 1992. Comparison by race of total serum IgG, IgA, and IgM with CD4 + T-cell counts in North American persons infected with the human immunodeficiency vinus type 1. J. Acquir. Immun. Defic. Syndr. 5:325-332.

61. Papadopulos-Eleopulos, E. 1988. Reappraisal of AIDS: Is the oxidation induced by the risk factors the primary cause? Med. Hypotheses 25:151-162.

62. Papadopulos-Eleopulos. E., Turner. V. F. and Papadimitriou, J. 1992. Kaposi's sarcoma and HIV. Med. Hypotheses 39:22-29.

63. Igel. H. J. Turner, H. C., Kotin. P. et al. 1969. Mouse leukaemia virus activation by chemical carcinogens. Science 166:624-1626.

64. Sterk. C. 1988. Cuxaine and HIV seropositivity. Lancet I: 1052-1053.

65. Kion, T. A. and Hoffmann. G. W. 1991. Anti-HIV and anti-anti-MHC antibodies in alloimmune and autoimmune mice. Science 253:1138-1140.

66. Conley, L. J. and Holmerg. S. D. 1992. Transmission of AIDS from blow screened negative for antibody to the human immunudeficiency virus. NEJM 326: 1499 .

67. Burgher, H., Weiser, B. Robinson, W. S. et al. 1985. Transient antibondy to lymphadenopathy-associated/human T-lymphotrophic virus type III and Tlymphocyte abnormalities in the wife of a man who developed the acquired immunodeficiency syndrome. Ann. Int. Med. 103:545-547.

68. Esteva, M. H., Blasini, A. M.. Ogly. D. and Rodriguez. M. A. 1992. False positive results from antibody to HIV in two men with systemic lupus erythrematosus. Ann. Rhem. Dis. 51:1071-1073.

69. Dummer, J. S., Erb, S., Breinig. M. K. et al. 1989. Infection with human immunodeficiency virus in the Pittsburgh transplant population. Transplantation 47:134-139.

70. Pitchenik, A. E. Burr. J. Suarez, M. et al. 1987. Human T-cell lymphotrophic virus-III (HTLV-III) seropositivity and related disease among 71 consecutive patients in whom tuberculosis was diagnosed. Am. Rev. Respir. Dis. 135:875-879.

71. Nzilambi, N.. Mann, J. M., Francis. H. et al. 1986. Seroprevalence among tuberculosis patients in Zaire. In: Abstracts II International AIDS Conference. Paris, No. 105:S17b.

72. St. Louis, M. E., Rauch, K. J., Peterson, L. R. et al. 1990. Seroprevalence rates of human immunodeficiency virus infection at sentinel hospitals in the United States. NEJM 323:213-218

73. Chamberland. M., Conley, L. and Dondero, T. 1988. Epidemiology of heterosexually acquired AIDS-United States, p. 264. In: Abstacts IV International AIDS Conference, Stockholm.

74. New York City AIDS Surveillance Report, January-March 1992

75. Rodriquez, L., Dewhurst, S., Sinangil. F. et al. 1985. Antibndies to HTLV-III/ LAV among aboriginal Amazonian Indians in Venezuela. Lancet II: 1098-1100.

76. Volsky, D. J., Wu, Y. T., Stevenson. M. et al. 1986. Antibodies to HTI.V-III LAV in Venezuclan patients with acute malarial syndromes. NEJM 314:647.

77. Rous, P. 1911. A Sarcoma of the fowl transmissible by an agent separable from the tumor cells. J. Exp. Med. 13:397-411.

78. Toplin. I. 1973. Tumor virus purification using zonal rotors. Spectra No. 4:225-235

79. Temin, H. M. and Baltimore, D. 1972. RNA-directed DNA synthesis and RNA tumor viruses. Adv: Vir. Res. 17:129-186.

80. RNA tumor viruses. 1982. R. Weiss, N. Teich, H. Varmus, J. Coffin (Eds.) Cold Spring Harbor Laboratory. Cold Spring Hartor. New York.

81. Bader, J. P. 1975. Reproduction of RNA tumor viruses, p. 253.331 . In Comprehensive Virology Vol. 4. H. Fraenkel-Conrat, R. R. Wagner (Fds.) Plenum Press, New York.

82. Sinoussi. F., Mendiola. L., Chermann, J. C. et al. 1973. Puritication and partial differentiation of the particles of murine sarcoma virus (M. MSV) according to their sedimentation rates in sucrose density gradients. Spectra No. $4: 237-243$.

83. Amiesen, J. C. and Capron, A. 1991. Cell dysfunction and depletion in AIDS the programmed cell death hypothesis. Immunol. Today 12:102-105.

84. Wyllie, A. H., Kerr, J. F. R. and Currie. A. R. 1980. Cell death: The significance of apoptosis. Int. Rev. Cytol. 68:252-306.

85. Hoxic. J. A., Fitzharris, T. P., Youngbar, P. R. et al. 1987. Nonrandom association of cellular antigens with HTLV-III virions. Hum. Immunol $18: 39-52$

86. McKeating. J. A. and Moore. J. P. 1991. HIV infectivity. Nature 349:660.

87. Masquelier. B. Combeau. I. and Poveda. J. 1991. In vitro assidys show a dissociation of reverse transcriptase activity and core antigen (p24) production in two HIV-1 isolates from a patient receiving long-term treatment with zidovudine (ZDV). J. Acquir. Immun. Defic. Syndr 4:499. 505.

88. Grunow, R., Valentin, A., Fenyo, F. M. et al. 1991 . Release of HIV-I core protein from infected cells independent of infectious virus particles, p. 157. In: Vol. I, Abstracts VII International Conference on AIDS, Florence, Italy.

89. Tedder, R. S., Semple. M. G., Tenant-Flowers. M. et at. 1992. HIV, AIDS. and ridovudine. Lancet 339:805-806.

90. Lemaitre, M., Guétard. D., Hénin, Y. et al. 1990. Protective activity of tetracycline analogs against the cytopathic effect of the human immunodeficiency viruses in CEM cells. Res. Virol. 141:5-16.

91. Boulerice, F., Bour, S. Geleziunas, R. et al. 1990. High frequency of isolation of defective human immunedeficiency virus type 1 and heterngeneity of viral genc expression in clones of infected U-937 cells. J. Virol. 64:1745-1755

92. Khrnst, A., Sonnerborg, A.. Bergdahl. S. and Strammegard, O. 1988. Efficient isolation of HIV from plasma during different stages of HIV infection. J. Med. Virol. 26:23-32.

93. Learmont. J.. Tindall, B., Evans, L. et at. 1992. I ong-term symptomless HIV-I infection in recipients of blond products from a single donor. Lancet 340:863-867.

94. Popovic, M., Sarngadharan, M. G., Read, F. ct al. 1984. Detection, isolation, and continuous production of cytopathic retroviruses (H TI,V-III) from patients with AIDS and pre-AIDS. Science 224:497-500.

95. Gallo, R. C.. Sarin. P. S. and Wu. A. M. 1973. On the nature of the nucleic acids and RNA dependent DNA polymerase from RNA tumor viruses and human cells. p. 13-34. In: Pussible F.pisomes in Eukaryotes. L. G. Silvestri (Ed.). North-Holiand Publishing Company. Amsterdam.

96. Whitkin, S. S., Higgins, P. J. and Bendich, A. 1978. Inhibition of reverse transcriplase and human sperm DNA polymerase by anti-sperm antibodies Clin. Exp. Immunol. 33:244-25!

97. Tomley, F. M. Armstrong, S. J. Mahy. B. W. J. and Owen. L. N. 1983 Reverse transcriptase activity and particles of retroviral density in cultured canine lymphosarcoma supernatants. Br. J. Cancer 47:277-284.

98. Weissbach, A.. Baltimore, D.. Bollum. F. et al. 1975. Nomenclature of euka ryotic DNA polymerases. Science 190:401-402

99. Gallo, R. C., Wong-Staal, F., Reitz, M. et al. 1976. Some evidence for infectious type-C virus in humans, p. 385-407. In: Animal Virology. D. Baltimore, A. S. Huang, C. F. Fox (Eds.). Academic Press Inc., New York.

100. Panem. S. Prochownik, E. V. Reale. F. R. et al. 1975. Isolation of type-C virions from a normal human fibroblast strain. Science 189:297-249

101. Panem, S. . Prochownik, E. V., Knish, W. M. and Kirsten, W. H. 1977. Cell generation and type-C virus expression in the human embryonic cell strain HEL-12. J. Gin. Virol. 35:487-495.

102. Panem, S. 1979. C-type virus expression in the placenta. Curr. Top. Pathol 66:175-189

103. Sarngadharan, M. G., Robert-Guroff, M. and Gallo. R. C. 1978. DNA poly merases of normal and neoplastic mammalian cells. Bicchim. Biophys. Acta. 516:419-487.

104. Klatzmann, D. Barré-Sinoussi, F. Nugeyre, M. T. et al. 1984. Selective tropism of lymphadenopathy assicciated virus (LAV) for helper-inducer I lymphocytes. Science 225:59-63.

105. Montagnier, L. 1985. Lymphadenopathy-associated virus: From molecular biology to pathogenicity. Ann. Int. Med 103:689-693.

106. Gendelman, H. E., Orenstcin, J. M.. Martin. M. A. et al. 1988. Efficien isolation and propagation of human immunodeficiency vinus on recombinant colony-stimulating factor l-treated monocytes. J. Exp. Med. 167:1428-1441.

107. Gelderblom, H. R. Hausmann, E. H. S. Ozel. M. et al. 1987. Fine structure of human immunodeficiency virus (HIV) and immunolocalization of structural proteins. Virol. 156: 171-176.

108. Gelderblom, H., Reupke. H. . Winkel, T. et al. 1987. MHC-antigens: Constitu ents of the envelopes of human and simian immunodeficiency viruses. 7 . Naturforsch. 42C:1328-1334.

109. Gelderblom. H. R. Reupke, H. and Pauli. G. 1985. Loss of envelope antigens of HTLV-III/LAV, a factor in AIDS pathogenesis? Lancet II: 1016-1017.

110. Neidrig. M.. Rabanus, J. P., LAge Stehr, J. et al. 1988. Monoclonal antibodie: directed against human immunodeficiency virus (HIV) gag proteins with specificity for conserved epitopes in HIV-1, HIV-2 and simian immunodeficiency virus. J. Gen. Virol. 69:2109-2114

111. Gelderblom, H. R., Özel, M., Hausmann, E. H. S. et al. 1988. Fine structure of human immunodeficiency virus (HIV). immunolocalization of structural proteins and virus-cell relation. Micron Microsc. 19:41-6().

112. Meerlo), T. Parmentier, H. K., Osterhaus, A et al. 1992. Modulation of ect surface molecules during HIV-I infection of $\mathrm{H} 9$ cells. An imnuneclectron microscopic study. AIDS 6:1105-1116.

113. Lecatsas, G. and Taylor. M. B. 1986. Pleomorphism in HTLV-III, the AIDS virus. S. Afr. Med. J. 69:793-794.

114. Hockley, D. J., Wood, R. D., Jacobs, J. P. et al. 1988. Electron microscopy of human immunndeficiency virus. J. Gen. Virol. 69:2455-2469.

115. Dourmashkin, R. R., O'T(x)le, (.. M., Bucher, D. and ()xford. J. S. 1991. The presence of budding virus-like particles in human lymphoid cells used for HIV cultivation. p. 122. In: Vol. I, Abstracts VII International Conference on AIDS Florence. Italy.

116. Brennan, J. K., Lichtman, M. A., Chamberlain, J. K. and Leblond, P. 1976. Isolation of variant lymphoma cells with reduced growth requirements for extracellular calcium and magnesium and enhanced oncogenicity. Blond 47:447-.459.

117. Garry, R. F. Fermin, C. D., Hart, D. J. et al. 1990. Detection of a human intracisternal A-type retroviral particle antigenically related to HIV. Science 250: $1127 \cdots 1129$

118. Amstrong. J. A and Horne. R. 1984. Follicular dendritic cells and virus-like particles in AIDS-related lymphadenopathy. Lancet II:370-372.

119. Tenner-Racz, K. Racz. P. Bofill, M. et al. 1986. HTLV-IH/LAV viral antigens in lymph nodes of homosexual men with persistent generalized lymphadenopathy and AIDS. Am. J. Pathol. 123:9-15.

120. Le Tourneau, A., Audouin. J., Dichold. J. et al. 1986. LAV-like viral particle: in lymph node germinal centers in patients with the persistent lymphadeno pathy syndrome and the acquired immunodeficiency syndmme-related complex. Hum. Pathol. 17: 1047-1053.

121. O'Hara. C. J.. Groopmen, J. F. and Federman, M. 1988. The ulerastructural and immunohistochemical demonstration of viral particles in lymph nodes from human immunodeficiency virus-related lymphadenopathy syndrornes. Hun. Pathol. 19:545.

122. Culliton, B. J. 1992. The mysterious virus called "isn't" Nature 358:619.

123. Chiodi. F. Alber, J. Olausson. E. et al. 1988. Isolation frequency of human immunodeficiency virus from cerehrospinal tluid and blexod of patients with varying severity of HIV infection. AIDS Res. Hum. Retroviruses 4:351-358.

124. Salahuddin, S. 7.. Groopman, J. E.. Markham, P. D. et al. 1984. HTLV-III symptom-free seronegative persons. Lancet II: 1418 - 1420.

125. Boussin. F. Rey, F., Dormont. D. et al. 1988. Isolation of HIV in a seronegative demented patient without symptoms of immune deficiency. Cancer Detect Prev. 12:257-265

126. Bayliss, G. J., Jesson, W. J., Evans, B. A et al. 1989. Isolation of HIV-I from small volumes of heparinized whole blood. AIDS 3:45-49.

127. Fiore, J. R., Angarano, G., Fico, C. et al. 1990. Cell cultures from small amounts of heparinized whole blood enhance HIV-1 isolation rate. AIDS 4:1295-1296 
128. Schüpbach, J., Jendis, J. B., Bron, C. et al. 1992. False-positive HIV-1 virus cultures using whole blood. AIDS 6: 1545-1546.

129. Hart, C., Spira, T., Moore, J. et al. 1988. Direct detection of HIV RNA expression in seropositive subjects. Lancet II:596-599.

130. Aaronson, S. A., Todaro, G. J. and Scholnick, E. M. 1971. Induction of murine C-type viruses from clonal lines of virus-free BALB/3T3 cells. Science 174: 157-159.

131. Hirsch, M. S., Phillips, S. M., Solnik, C. et al. 1972. Activation of leukemia viruses by graft-versus-host and mixed lymphocyte reactions in vitro. Proc. Nat. Acad. Sci. 69:1069-1072.

132. Toyoshima, K. and Vogt, P. K. 1969. Enhancement and inhibition of avian sarcoma vinuses by polycations and polyanions. Virol. 38:414-426.

133. Nakamura, N., Sugino, H., Takahara, K. et al. 1991. Endogenous retroviral LTR DNA sequences as markers for individual human chromosomes. Cytogenet. Cell Genet. 57:18-22.

134. Varmus, H. and Brown, P. 1989. Retroviruses, p. 53-108. In: Mobile DNA. D. E. Berg, M. M. Howe (Eds.). American Society for Microbiology. Washington, D. C.

135. Weiss, R. A., Friis, R. R., Katz, E. et al. 1971. Induction of avian tumor viruses in normal cells by physical and chemical carcinogens. Virol. 46:920938.

136. Temin, H. M. 1974. On the origin of RNA tumor viruses. Harvey Lect. 69:173-197.

137. Wain-Hobson, S. and Myers, G. 1990. Too close for comfort. Nature 347:18

138. Genetics of RNA tumour viruses. 1973. p. 656-699. In: The molecular biology of tumour viruses. J. Tooze (Ed.). Cold Spring Harbor Laboratory, Cold Spring Harbor, New York.

139. Saag, M. S., Hahn, B. H., Gibbons, J. et al. 1988. Extensive variation of human immunodeficiency virus type-1 in vivo. Nature 334:440.

140. Marx, J. L. 1988. The AIDS virus can take on many guises. Science 241:10391040.

141. von Briesen, H., Becker, W. B., Henco, K. et al, 1987. Isolation frequency and growth properties of HIV-variants: Multiple simultaneous variants in a patient demonstrated by molecular cloning. J. Med. Virol. 23:51-66.

142. Bolton, V., Pedersen, N. C., Higgins, J. et al. 1987. Unique p24 epitope marker to identify multiple human immunodeficiency virus variants in blood from the same individuals. J. Clin. Microbiol. 25: 1411-1415.

143. Wain-Hobson, S. 1989. HIV genome variability in vivo. AIDS 3:S13-S18.

144. Innocenti, P., Ottmann, M., Morand, P. et al. 1992. HIV-1 blood monocytes: Frequency of detection of proviral DNA using PCR in comparison with the total CD4 count. AIDS Res. Hum. Retroviruses 8:261-268.

145. Meyerhans, A., Cheynier, R., Albert, J. et al. 1989. Temporal fluctuations in HIV quasispecies in vivo are not reflected by sequential HIV isolations. Cell 58:901-910.

146. Robey, W. G., Nara, P. L., Poore, C. M. et al. 1987. Rapid assessment of relationships among HIV isolates by oligopeptide analyses of external envelope glycoproteins. AIDS Res. Hum. Retroviruses 3:401-408.

147. Shaw, G. M., Hahn, B. H., Suresh, K. A. et al. 1984. Molecular characterization of human T-cell leukemia (lymphotropic) virus type III in the acquired immune deficiency syndrome. Science 226:1165-1171.

148. Simmonds, P., Balfe, P., Peutherer, J. F. et al, 1990. Human immunodeficiency virus-infected individuals contain provirus in small numbers of peripheral mononuclear cells and at low copy numbers. J. Virol. 64:864-872.

149. Van Voorhis, B. J., Martinez, A., Mayer, K. and Anderson, D. J. 1991 Detection of human immunodeficiency virus type 1 in semen from seropositive men using culture and polymerase chain reaction deoxyribonucleic acid amplification techniques. Fertil. Steril. 55:588-594.

150. Defer, C., Agut, H., and Garbarg-Chenon, A. 1992. Multicentre quality control of polymerase chain reaction for detection of HIV DNA. AIDS 6:659663.

151. Bocker, J. L., Hazan, U., Nugeyre, M. T. et al. 1986. Infection of insect lines by HIV, agent of AIDS, and evidence for HIV proviral DNA in insects from Central Africa. C.R. Acad. Sci. Paris. 300:303-306.

152. Arya, S. K., Gallo, R. C., Hahn, B. H. et al. 1984. Homology of genome of AIDS-associated vinus with genomes of human T-cell leukemia viruses. Science 225:927-930.

153. Mager, D. L. and Freeman, J. D. 1987. Human endogenous retroviruslike genome with type $\mathrm{C}$ pol sequences and gag sequences related to human T-cell lymphotropic viruses. J. Virol. 61:4060-4066.

154. Banki, K., Maceda, J., Hurley, E. et al. 1992. Human T-cell lymphotropic virus (HTLV)-related endogenous sequence, HRES-1 encodes a $28-\mathrm{kDa}$ protein: a possible autoantigen for HTLV-I gag-reactive autosntibodies. Proc. Natl. Acad. Sci. 89:1939-1943.

155. Webster, A. D. B., Dalgleish, A. G., Beattie, R. et al. 1986. Isolation of retroviruses from two patients with "common variable" hypogammaglobulinaemia. Lancet I:581-582.

156. Ciampolillo, A., Marini, V. and Buscema, M. 1989. Retrovirus-like sequences in Graves' disesse: Implications for human autoimmunity. Lancet I: $1096-1100$.

157. Horwitz, M. S., Boyce-Jacino, M. T. and Faras, A. J. 1992. Novel human endogenous sequences related to human immunodeficiency virus type 1 . J. Virol. 66:2170-2179.

158. Farzadegan, H., Polis, M., Wolinsky, S.M et al 1988. Loss of human immunodeficiency virus type 1 (HIV-1) antibodies with evidence of viral. infection in asymptomatic homosexual Men. Ann. Int. Med. 108:785-790

159. Horsburgh, C. R., Ou, C. Y., Holmberg, S. D. et al. 1989. Human immunodeficiency virus type 1 infection in homosexual men who remain seronegative for prolonged periods. NEJM 321: 1678-1680.

160. Mikovits, J. A., Lohrey, N., Schuloff, R., Ruscetti, F. 1991. Immune activation of latent HIV-1 expression in monocyte/macrophages, p. 151. In: Vol. I, Abstracts VII International Conference on AIDS, Florence, Italy.

161. Vartanian, J. P., Meyerhans, A., Henry, M. and Wain-Hobson, S. 1992. Highresolution structure of an HIV-1 quasispecies: Identification of novel coding sequences. AIDS 6: 1095-1098.
VIRUS SAFE

Foetal Calf Serum

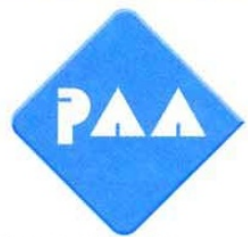

Raw materials for cell culture many contribute a number of potential safety considerations.

The materials employed for cell propagation usually have the same risks as primary cells, ie presense of adventitious agents (particularly viruses and mycoplasma). While effective in identifying heavily contaminated batches, virus testing has inherent limitations in terms of sample size, sampling plan, statistical variations, sensitivity of the test method and costs.

To eliminate these shortcomings PAA have

introduced a proprietary technology for the inactivation of viruses in Foetal Calf Serum. This new process destroys the viral DNA or RNA assuring :-

- Inactivation of common bovine virues including:- BVD, IBR and PI-3 viruses

No effect on proteins/cell growth

No reduction of shelf life

- Elimination of contamination risk

\section{To obtain a Technical Brochure or to request a free of charge sample \&} reservation contact your local sales office.
International Office \& United Kingdom
Head Office
Austria

Tel $(+44) 207582993$

Fax (+44) 207583002

Tel (+43) 73249351300

Fax (+44) 73248273

Germany

United States

Tel (+49) 642166681

Fax (+49) 642165897

Tel (+1) 3104309297

Fax (+1) 3109821432

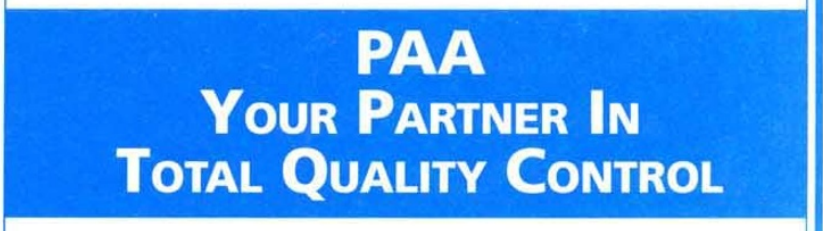

Write in No. 480 on Reader Service Card 